\title{
Mechanism of persistent infection associated with peritoneal implants
}

\author{
K. H. WARD, M. E. OLSON, K. LAM and J. W. COSTERTON*
}

Department of Biological Sciences, Division of Cellular and Microbial Biology, University of Calgary, Calgary, Alberta T2N $1 \mathrm{~N} 4$, Canada

\begin{abstract}
Summary. The ability of rabbits to clear an intraperitoneal injection of Pseudomonas aeruginosa in the presence or absence of a surgically implanted peritoneal device was investigated. Sham-operated rabbits without an implant eliminated a $P$. aeruginos $a$ challenge of $5 \times 10^{6} \mathrm{cfu} / \mathrm{ml}$; lavage fluid and peritoneal tissues became culture-negative within $96 \mathrm{~h}$. However, peritonitis developed in rabbits that were given the same number of bacteria in the presence of an implant; high bacterial counts were recovered from the lavage fluid and the device itself. Scanning and transmission electronmicroscopy revealed bacterial biofilms on the surface of the device. Insertion of pre-colonised devices demonstrated a rapid multiplication of sessile organisms within the resulting bacterial biofilm. Counts reached a plateau of about $1 \times 10^{7} \mathrm{cfu} / \mathrm{cm}^{2}$ of Silastic by day 16 and fluctuated around this level until the end of the study. Pre-immunisation with formalin-killed whole cells of $P$. aeruginosa did not reduce this bacterial growth despite high levels of specific IgG. The results confirm the failure of peritoneal defences to clear an infection in the presence of an implant following either challenge with planktonic bacteria or insertion of a pre-colonised device, and demonstrate the rapid development of bacterial biofilms on the surface of the implant which appear to protect the bacteria from host defences, even when primed by pre-immunisation.
\end{abstract}

\section{Introduction}

An increasing number of prosthetic devices are implanted into patients for both short and long term medical applications, and several of these are placed within the peritoneal cavity. These include aortic interposition grafts, peritoneovenous shunts, ventriculoperitoneal shunts, $t$-tubes and peritoneal dialysis catheters, all of which are susceptible to infection. ${ }^{1}$ In addition to gram-positive bacteria, many intraperitoneal devices are also prone to contamination with gram-negative and anaerobic organisms which may be enteric in origin. ${ }^{1-4}$ Such infections are generally more serious than those due to gram-positive organisms and require aggressive chemotherapy. ${ }^{1.2}$

It has been proposed that erosion of the device into the bowel lumen, ${ }^{5-7}$ intraperitoneal infections such as appendicitis, ${ }^{8}$ or even translocation of bacteria across the bowel wall ${ }^{9.10}$ may lead to contamination of intraperitoneal devices with gram-negative or anaerobic bacteria. In the case of Tenckhoff catheters used for continuous ambulatory peritoneal dialysis, contamination of dialysis fluid or tracking of bacteria from the skin along the catheter into the peritoneum may represent other routes of infection. ${ }^{1}$ Concomitant gastrointestinal surgery may also release enteric bac-

Received 22 April 1991 ; accepted 6 Aug. 1991

* Correspondence should be sent to Dr J. W. Costerton. teria in the vicinity of the implant. ${ }^{1}$ In all situations, infection results in considerable morbidity and even mortality ${ }^{2}$ and frequently can only be resolved by removal of the device. ${ }^{1-3}$

There is considerable clinical evidence that implantation of a foreign body predisposes patients to infection, ${ }^{11.12}$ and in many cases these chronic infections have been associated with the presence of bacterial biofilms on the surface of the device. ${ }^{13-16}$

Several animal models have been designed to examine this potentiation of infection $;^{17-20}$ however, these have predominantly involved subcutaneous implants and planktonic bacteria, and the peritoneum has largely been ignored. The aims of this study were to examine the effect of a foreign body in the peritoneum on the ability of rabbits to eliminate an intraperitoneal (i.p.) challenge by planktonic cells and pre-formed biofilms of Pseudomonas aeruginosa, and to compare the growth of $P$. aeruginosa within a biofilm on a peritoneal device in naive rabbits and rabbits with specific humoral immunity.

\section{Materials and methods}

\section{Bacteria and culture conditions}

The laboratory strain $P$. aeruginosa $\mathrm{PAO}-1^{21}$ was used throughout this study. Bacteria were maintained on Nutrient Agar (Difco) slopes at $-70^{\circ} \mathrm{C}$. Cells were 
cultivated overnight in a chemically-defined medium lacking iron $(\mathrm{CDM}-\mathrm{Fe})^{22}$ at $37^{\circ} \mathrm{C}$ in an orbital shaker, and harvested by centrifugation at $1600 \mathrm{~g}$ for $10 \mathrm{~min}$. Bacterial pellets were washed in sterile phosphate-buffered saline (PBS), then resuspended to the required density. The number of viable bacteria was confirmed by quantitative plating on to nutrient agar.

\section{Animals}

Adult female New Zealand white rabbits (Vandermeer C., Sherwood Park, Alberta, Canada) weighing $3-3 \cdot 5 \mathrm{~kg}$ were used in all experiments. Care, housing and treatment of animals were conducted in accordance with the Guidelines for the Care and Use of Experimental Animals (Canadian Council of Animal Care, Ottawa, Ontario).

\section{Implant device}

Disks $(1.5 \mathrm{~cm}$ diameter $)$ of Silastic ${ }^{\circledR}$ subdermal implant material (Dow Corning Corp., Medical Products, Midland, MI, USA) were attached to both sides of eight teflon support disks of the same diameter, and a teflon rod $(4.0 \mathrm{~cm}$ long) was inserted through a hole in the centre of each disk (fig. 1). The total surface area of Silastic for each device was $32 \mathrm{~cm} .^{2}$ Devices were sterilised with ethylene oxide for $4 \mathrm{~h}$. Under halothane anaesthesia the rabbit abdomen was shaved and disinfected with Betadine (Perdue Fredricton Co., Toronto, Ontario, Canada). A midline incision was made and a sterile device was implanted aseptically into the peritoneal cavity. Devices colonised with $P$. aeruginosa were implanted into some rabbits (see below). The peritoneal fascia and subcutaneous layer were closed with 3-O absorbable polyglycolic acid sutures (Vicryl ${ }^{\circledR}$, Ethicon Ltd, Peterborough, Ontario, Canada) and the skin with 3-O propylene monofilament sutures (Prolene ${ }^{\circledR}$, Ethicon Ltd). Sham operations were performed on Group 1 and 2 rabbits (see below) but no device was implanted. All rabbits were allowed to recover from surgery before further experimentation.

\section{Intraperitoneal injection of planktonic bacteria in the presence or absence of a device}

Rabbits were allocated into the following groups: no peritoneal implant, no i.p. inoculation of bacteria

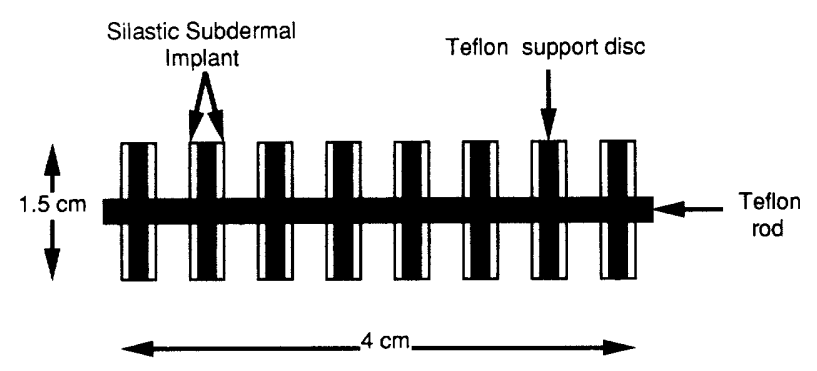

Fig. 1. Diagrammatic representation of the implant device.
(Group 1, $\mathrm{n}=6$ ); no peritoneal implant, i.p. inoculation of planktonic bacteria (Group 2, $\mathrm{n}=6$ ); peritoneal implant, no i.p. inoculation of bacteria (Group $3, \mathrm{n}=6$ ); peritoneal implant, i.p. inoculation of planktonic bacteria (Group 4, $\mathrm{n}=6$ ). Rabbits in Groups 2 and 4 were given $1 \mathrm{ml}$ of a $P$. aeruginosa suspension $\left(5 \times 10^{6} \mathrm{cfu} / \mathrm{ml}\right.$ in PBS $)$ by i.p. injection. Peritoneal lavage with $100 \mathrm{ml}$ of sterile PBS was performed under halothane anaesthesia on three rabbits from each of the four groups, $24 \mathrm{~h}$ and $96 \mathrm{~h}$ after surgery. Lavage fluid was cultured directly or after centrifugation at $1600 \mathrm{~g}$ for $10 \mathrm{~min}$ and resuspension in $300 \mu$ of PBS. Cellular constituents were examined by Diff Quik stain (American Scientific Products, American Hospital Supply Corp., McGaw Park, IL, USA) on smears of the concentrated fluid. Rabbits were then killed by intravenous (i.v.) pentobarbital (Somnitol ${ }^{\circledR}$, MTC Pharmaceuticals, Cambridge, Ontario, Canada) overdose, and any devices present, along with samples of adjacent peritoneum, were removed for histological and microbiological assessment. One disk from the device was used for viable counts and one for scanning and transmission electronmicroscopy. A blood sample $(5 \mathrm{ml})$ collected by ear vein puncture before surgery and before each lavage was inoculated into $25 \mathrm{ml}$ of sterile Tryptic Soy Broth (Difco) and incubated at $37^{\circ} \mathrm{C}$ for 7 days. If turbidity developed, a loopful of broth was streaked on to nutrient agar.

\section{Implantation of pre-colonised devices}

For Group 5 rabbits (non-immune, $\mathrm{n}=18$ ) sterile devices were pre-colonised with $P$. aeruginosa by incubation for $2 \mathrm{~h}$ at $37^{\circ} \mathrm{C}$ in a bacterial suspension of $1 \times 10^{5} \mathrm{cfu} / \mathrm{ml}$ of PBS on a rocking platform. Devices were rinsed in sterile PBS to remove non-adherent bacteria and implanted into the rabbit peritoneum as described above or were used to determine viable counts of adherent bacteria. Groups of three rabbits were killed 2, 4, 8, 16, 28 and 42 days after insertion. Devices and samples of the liver and spleen and any tissues with suspected infection were removed for microbiological culture. A blood sample $(10 \mathrm{ml})$ was obtained for culture before administration of the barbiturate overdose, and a portion was allowed to clot for removal of serum. Sera from each group of three rabbits on each sampling day was pooled and stored at $-70^{\circ} \mathrm{C}$ for immunological studies. Control rabbits (Group 6, $\mathrm{n}=6$ ) into which non-colonised devices were implanted, were killed on days 4 and 28 only.

\section{Implantation of pre-colonised devices in immunised rabbits}

Rabbits (Group 7, $\mathrm{n}=18$ ) were immunised with formalin-killed whole cells of $P$. aeruginosa grown in $\mathrm{CDM}-\mathrm{Fe}$. Formaldehyde (final concentration $3.7 \%$ ) was added to an overnight culture of bacteria and the 
culture was left for $48 \mathrm{~h}$ at room temperature. Killed bacteria were pelleted by centrifugation at $1600 \mathrm{~g}$ for $10 \mathrm{~min}$, washed twice in PBS, resuspended in PBS and emulsified in Freund's complete adjuvant (first immunisation) or Freund's incomplete adjuvant (three subsequent immunisations). Immunisation was by intramuscular (i.m.) injection of $1 \mathrm{ml}$ of emulsion in both hind legs. Devices were colonised and implanted into the peritoneum as in Group 5 rabbits. Three rabbits were killed on days $2,4,8,16,28$ and 42 and post-mortem examination was performed as for rabbits in Groups 5 and 6.

\section{Quantitative bacterial counts}

To determine counts of surface adherent (sessile) bacteria, devices were dismantled and the Silastic surfaces were scraped with a sterile scalpel blade into $10 \mathrm{ml}$ of sterile PBS. PBS, scrapings and Silastic were vortex mixed for $1 \mathrm{~min}$ and subjected to low intensity sonication (Bransonic 220; Branson Ultrasonics Corp. Danbury, CT, USA) for $5 \mathrm{~min}$ to detach remaining adherent bacteria. ${ }^{23}$ The disks were removed and the suspension was homogenised with three 30-s bursts (Polytron Brinkman Homogeniser; Kinematica AG, Switzerland) to break up bacterial clumps. Duplicate 10-fold dilutions were made in PBS and a $0 \cdot 1-\mathrm{ml}$ sample from each dilution was plated on to nutrient agar. Bacterial colonisation of the device was expressed as $\mathrm{cfu} / \mathrm{cm}^{2}$ of Silastic. Tissue samples were weighed, then homogenised in $5 \mathrm{ml}$ of PBS, diluted and plated as above. Peritoneal lavage fluid, before and after concentration by centrifugation, was similarly plated.

\section{Enzyme-linked immunosorbent assay (ELISA)}

Rabbit serum IgG titres to $P$. aeruginosa whole cells were determined by ELISA, based on the method of Ogawa et al. ${ }^{24}$ Briefly, 72 wells of a 96-well flatbottomed micro-ELISA plate (Linbro/Titertek, Flow Laboratories Inc., McLean, VA, USA) were coated with formalin-killed whole cells of $P$. aeruginosa resuspended to $5 \times 10^{8} \mathrm{cfu} / \mathrm{ml}$ in $0.1 \mathrm{M}$ carbonate buffer, pH 9.6 (150 $\mu \mathrm{l} /$ well). To create a standard curve, remaining wells were coated with anti-rabbit IgG (Cappel, Organon Teknika Corp., PA, USA) diluted 1 in 10000 in carbonate buffer. After coating at $4^{\circ} \mathrm{C}$ for $18 \mathrm{~h}$, plates were washed with PBS containing Tween 20 (PBS-Tween) $0.1 \%$ and blocked in PBSTween containing bovine serum albumin (PBS-TweenBSA) $0.5 \%$ for $1 \mathrm{~h}$ at room temperature. Rabbit sera appropriately diluted in PBS-Tween-BSA were added in triplicate to $P$. aeruginosa-coated wells $(100 \mu \mathrm{l} /$ well). For the standard curve, doubling dilutions of purified rabbit IgG (Cappel) in PBS-TweenBSA were added in triplicate to the remaining wells (100 $\mu \mathrm{l} /$ well). Plates were left overnight at room temperature and washed thoroughly. All wells were then incubated in peroxidase-labelled anti-rabbit IgG
(Cappel), diluted 1 in 25000 in PBS-Tween-BSA, for $2 \mathrm{~h}$ at room temperature $(100 \mu \mathrm{l} /$ well). Plates were washed again and $100 \mu$ l of enzyme substrate $(O$ phenylene diamine $40 \mathrm{mg}$ and $\mathrm{H}_{2} \mathrm{O}_{2} 30 \% \mathrm{v} / \mathrm{v} 100 \mu \mathrm{l}$ in $100 \mathrm{ml}$ of $0 \cdot 1 \mathrm{M}$ citrate buffer) was added to each well. The colour reaction was stopped after $30 \mathrm{~min}$ by the addition of $150 \mu \mathrm{l}$ of $2.5 \mathrm{M}$ sulphuric acid. Absorbance of the wells was measured at $492 \mathrm{~nm}$ by a Titertek Multiscan ELISA reader (Flow Laboratories Inc.). Calibration curves were constructed based on a loglogit transformation and linear regression analysis with correlation coefficients greater than $0 \cdot 98 .^{23}$ Each serum was assayed on at least three separate occasions. Titres of anti- $P$. aeruginosa IgG in serum were expressed as $\mathrm{mg}$ of $\mathrm{IgG} / \mathrm{ml}$.

\section{Electronmicroscopy}

Disks were fixed for $2 \mathrm{~h}$ at room temperature in glutaraldehyde $5 \%$ in $0.1 \mathrm{~m}$ cacodylate buffer $(\mathrm{pH} \mathrm{7.2)}$ containing ruthenium red $0 \cdot 15 \%$. For transmission electronmicroscopy (TEM), the surface of the disk was scraped with a sterile scalpel blade and the scrapings were enrobed in Bacto Agar (Difco) 4\%. Samples were washed five times with cacodylate buffer and post-fixed in osmium tetroxide $2 \%$ in cacodylate buffer for $2 \mathrm{~h}$ at room temperature. Samples were dehydrated and embedded in Spurr low viscosity resin (Electron Microscopy Sciences, Quebec, Canada). Sections were stained with uranyl acetate and lead citrate and examined on a Hitachi 600 transmission electronmicroscope (Hitachi, Tokyo, Japan) at $50 \mathrm{kV}$.

For scanning electronmicroscopy (SEM), samples were fixed as described above, washed five times in cacodylate buffer, dehydrated in a graded series of ethanol, and air dried. The Silastic was mounted on stubs, sputter-coated with gold: palladium $(60: 40)$ and examined with a Hitachi S-450 scanning electronmicroscope at an accelerating voltage of $20 \mathrm{kV}$.

\section{Statistical analysis}

Bacterial counts were transformed to $\log _{10}$ values. Data were analysed by a one-way analysis of variance followed by testing for least significant difference.

\section{Results}

Intraperitoneal injection of planktonic bacteria in the presence or absence of a device

Peritoneal lavage fluids from rabbits that had no implant and did not receive a bacterial i.p. injection (Group 1) were free of any bacteria (table I). There were few host cells in the lavage fluid and the majority $(95 \%)$ of those present were macrophages (table II). No polymorphonucleocytes (PMNs) were observed. After i.p. injection of $1 \mathrm{ml}$ of bacterial suspension (c. $5 \times 10^{6} \mathrm{cfu} / \mathrm{ml}$ ), rabbits with no implant device (Group 2) rapidly cleared the infection (table I). 
Table I. Recovery of $P$. aeruginosa from lavage fluid and implants from rabbits

\begin{tabular}{|c|c|c|c|c|c|c|c|c|}
\hline \multirow{3}{*}{$\begin{array}{l}\text { Time } \\
\text { after } \\
\text { surgery }\end{array}$} & \multicolumn{8}{|c|}{ Mean (SEM) number of $P$. aeruginosa recovered from rabbits in } \\
\hline & \multicolumn{2}{|c|}{$\begin{array}{c}\text { Group 1 } \\
\text { (no implant, } \\
\text { no i.p. bacteria) }\end{array}$} & \multicolumn{2}{|c|}{$\begin{array}{c}\text { Group 2 } \\
\text { (no implant, } \\
\text { i.p. bacteria) }\end{array}$} & \multicolumn{2}{|c|}{$\begin{array}{c}\text { Group 3 } \\
\text { (implant, } \\
\text { no i.p. bacteria) }\end{array}$} & \multicolumn{2}{|c|}{$\begin{array}{c}\text { Group } 4 \\
\text { (implant, } \\
\text { i.p. bacteria) }\end{array}$} \\
\hline & Lavage* & Implant $\uparrow$ & Lavage & Implant & Lavage & Implant & Lavage & Implant \\
\hline $24 \mathrm{~h}$ & NG & $\ldots$ & $0.59(0.38)$ & $\ldots$ & NG & NG & $2.94(0.31)$ & $5.84(0.03)$ \\
\hline $96 \mathrm{~h}$ & NG & $\ldots$ & NG & $\ldots$ & NG & NG & $1.50(0.87)$ & $6 \cdot 41(0.15)$ \\
\hline
\end{tabular}

NG, no growth.

* $\log _{10} \mathrm{cfu} / \mathrm{ml}$.

$\dagger \log _{10} \mathrm{cfu} / \mathrm{cm}^{2}$ of Silastic.

Table II. Cellular constituents of lavage fluid from rabbits

\begin{tabular}{|c|c|c|c|c|c|c|c|c|}
\hline \multirow{3}{*}{ Cell type } & \multicolumn{8}{|c|}{ Mean numbers and percentages of cells in fluid from rabbits in } \\
\hline & \multicolumn{2}{|c|}{$\begin{array}{c}\text { Group 1 } \\
\text { (no implant } \\
\text { no i.p. bacteria) }\end{array}$} & \multicolumn{2}{|c|}{$\begin{array}{c}\text { Group 2 } \\
\text { (no implant, } \\
\text { i.p. bacteria) }\end{array}$} & \multicolumn{2}{|c|}{$\begin{array}{c}\text { Group 3 } \\
\text { (implant, } \\
\text { no i.p. bacteria) }\end{array}$} & \multicolumn{2}{|c|}{$\begin{array}{c}\text { Group } 4 \\
\text { (implant, } \\
\text { i.p. bacteria) }\end{array}$} \\
\hline & $24 \mathrm{~h}$ & $96 \mathrm{~h}$ & $24 \mathrm{~h}$ & $96 \mathrm{~h}$ & $24 \mathrm{~h}$ & $96 \mathrm{~h}$ & $24 \mathrm{~h}$ & $96 \mathrm{~h}$ \\
\hline $\begin{array}{l}\text { Total cell numbers } \\
\text { PMNs }(\%) \\
\text { Mesothelial cells (\%) } \\
\text { Macrophages (\%) }\end{array}$ & $\begin{array}{r}+ \\
0 \\
5 \\
95\end{array}$ & $\begin{array}{r}+ \\
0 \\
5 \\
95\end{array}$ & $\begin{array}{c}++ \\
38 \\
11 \\
51\end{array}$ & $\begin{array}{r}+ \\
2 \\
7 \\
91\end{array}$ & $\begin{array}{l}++ \\
25 \\
10 \\
65\end{array}$ & $\begin{array}{l}++ \\
26 \\
13 \\
61\end{array}$ & $\begin{array}{c}+++ \\
69 \\
4 \\
27\end{array}$ & $\begin{array}{c}++ \\
60 \\
5 \\
35\end{array}$ \\
\hline
\end{tabular}

+ , Low,++ , moderate, +++ , high

Numbers represent an average for three rabbits in each group.

Although low numbers of $P$. aeruginosa were cultured from lavage fluid $24 \mathrm{~h}$ after bacterial challenge, fluid and concentrated fluid were sterile in all three rabbits killed at $96 \mathrm{~h}$. A moderate number of host cells were present (table II) at $24 \mathrm{~h}$, of which a significant proportion ( $38 \%$ ) were PMNs. By $96 \mathrm{~h}$, the number of PMNs had fallen to $2 \%$ and the vast majority of cells were macrophages. On gross observation, the peritoneal cavity appeared normal in all Group 2 rabbits.

Lavage fluids from rabbits with a peritoneal device but not inoculated with organisms (Group 3) had moderate numbers of cells but remained sterile (tables I and II). PMNs comprised about $25 \%$ of the total cell content at both 24 and $96 \mathrm{~h}$. On post-mortem examination at $96 \mathrm{~h}$, the tissue surrounding the implant was hyperemic and the implant itself had a thin coating of purulent material, but remained sterile. In Group 4 rabbits, which received an implant and were inoculated i.p. with bacteria, large numbers of $P$. aeruginosa were recovered in the lavage fluid (table I). Bacterial counts were slightly lower at $96 \mathrm{~h}$ and in one rabbit the fluid was sterile suggesting possible clearance of these planktonic organisms. However, all of the devices became colonised with $P$. aeruginos $a$ with mean counts of $c .7 \times 10^{5} \mathrm{cfu} / \mathrm{cm}^{2}$ at $24 \mathrm{~h}$, increasing to $c .3 \times$ $10^{6} \mathrm{cfu} / \mathrm{cm}^{2}$ by $96 \mathrm{~h}$. There were large numbers of host cells in the lavage fluid samples (table II), PMNs being the predominant cell type at both $24 \mathrm{~h}$ and $96 \mathrm{~h}(69 \%$ and $60 \%$ respectively). A severe inflammatory re- action was apparent in the tissue surrounding the device and consisted of a significant quantity of purulent material and fibrin. The peritoneal wall and mesentery associated with the device were severely inflamed. All tissue greater than $1 \mathrm{~cm}$ from the device appeared normal on gross examination. The device was coated with a thick layer of pus and fibrin.

Blood cultures from all groups of rabbits were negative at all times.

When devices from Group 4 rabbits were examined by SEM, a thick biofilm layer covering most of the disk surface was seen (fig. 2A) and many white cells were observed in it. In some areas, fissures in the biofilm surface revealed rod-shaped bacteria partially covered with the dehydrated remains of biofilm material (fig. 2B). TEM of scrapings from colonised devices that were removed from rabbits demonstrated characteristic gram-negative bacteria (fig. 3), surrounded by exopolysaccharide glycocalyx (arrows). Interestingly, biofilms were also observed on devices removed from Group 3 rabbits, but no bacteria were visible (not shown).

Implantation of pre-colonised devices in naive and preimmunised rabbits

To challenge animals with pre-formed biofilm bacteria, to more accurately follow growth of bacteria on the implant surface with time, and to compare this 

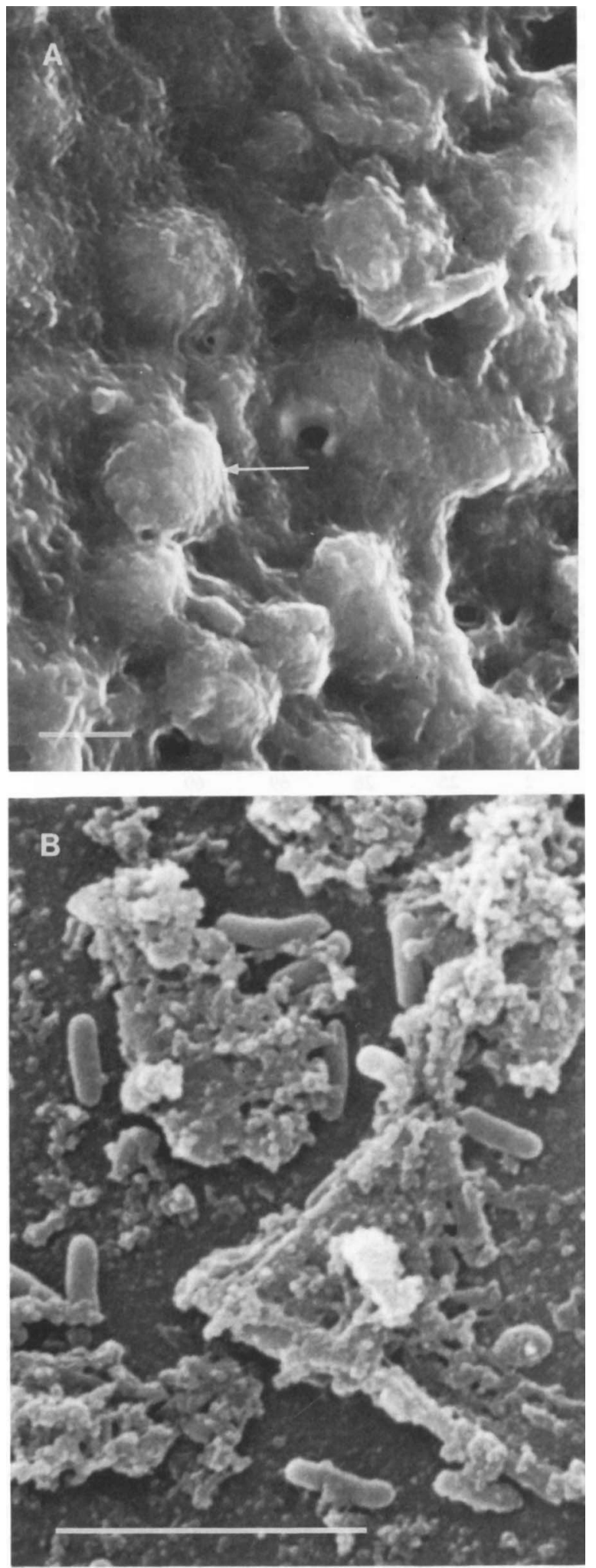

Fig. 2. Scanning electronmicrographs of biofilm on the Silastic disks. Most of the surface is covered with extensive biofilm (A) of host and bacterial origin. Many white cells are visible (arrow). Cracks in the biofilm caused by sample dehydration reveal rod-shaped bacteria partially occluded by the collapsed remains of the biofilm (B). Bar $=5 \mu \mathrm{m}$.

growth in pre-immunised rabbits, devices were precolonised with a known number of adherent $P$. aeruginosa $\left(c .1 .5 \times 10^{4} \mathrm{cfu} / \mathrm{cm}^{2}\right)$. These devices were then implanted into the peritoneum of non-immunised

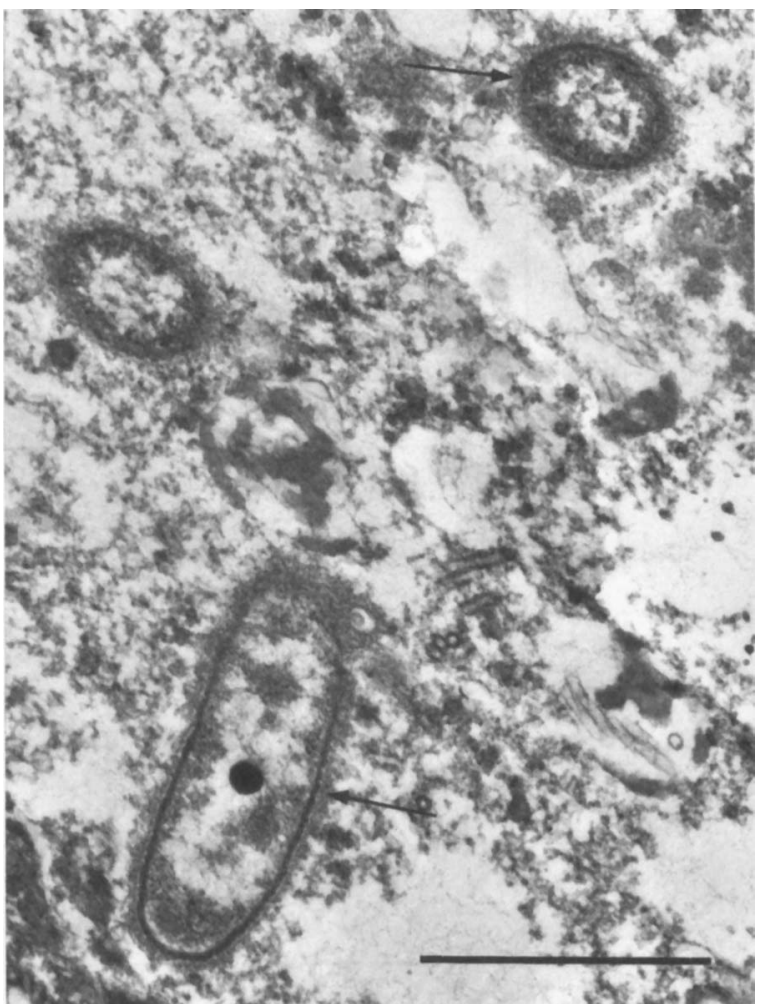

Fig. 3. Transmission electronmicrograph of scrapings from an infected device. Bacteria are seen surrounded by glycocalyx material (arrows). Bar $=1 \mu \mathrm{m}$

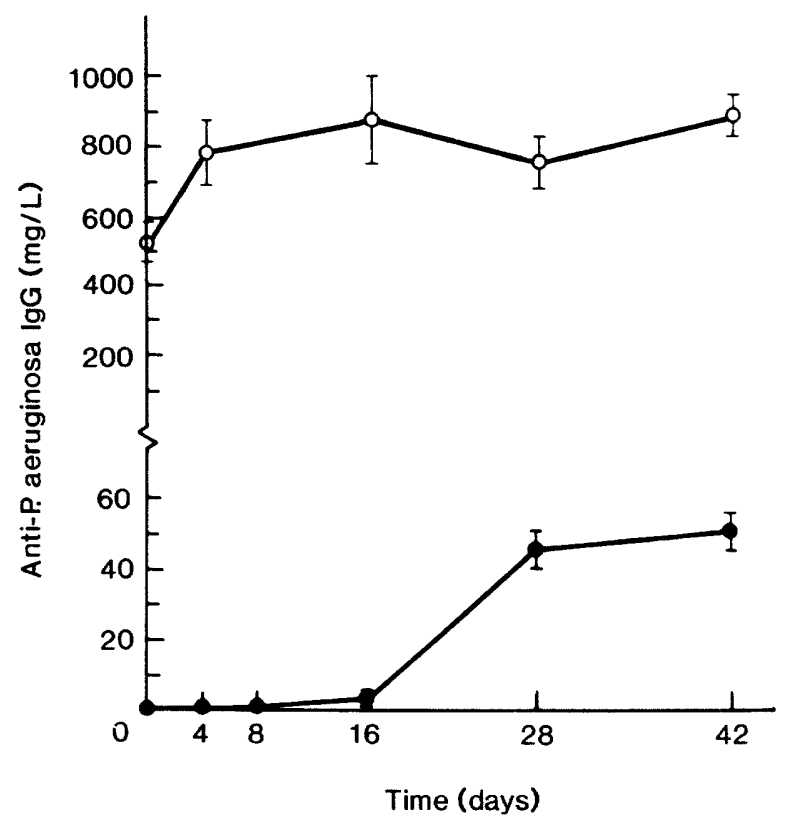

Fig. 4. Anti- $P$. aeruginosa IgG concentrations in serum from Group 5 , non-immunised $(-)$ and Group 7 , immunised $(O)$ rabbits during the course of infection. Serum from three rabbits on each sampling day was pooled and assayed in triplicate. Each point is a mean value and bars represent SEM.

(Group 5) or immunised (Group 7) rabbits. Before insertion of colonised devices, serum levels of anti- $P$. aeruginosa IgG in non-immunised rabbits were $<0.5 \mathrm{mg} / \mathrm{L}$ (fig. 4). After day 16 in this group, a modest rise was observed, reaching $c .50 \mathrm{mg} / \mathrm{L}$ by day 42. Immunised rabbits had 1000-fold higher levels of specific antibody (c. $530 \mathrm{mg} / \mathrm{L})$ than non-immunised 


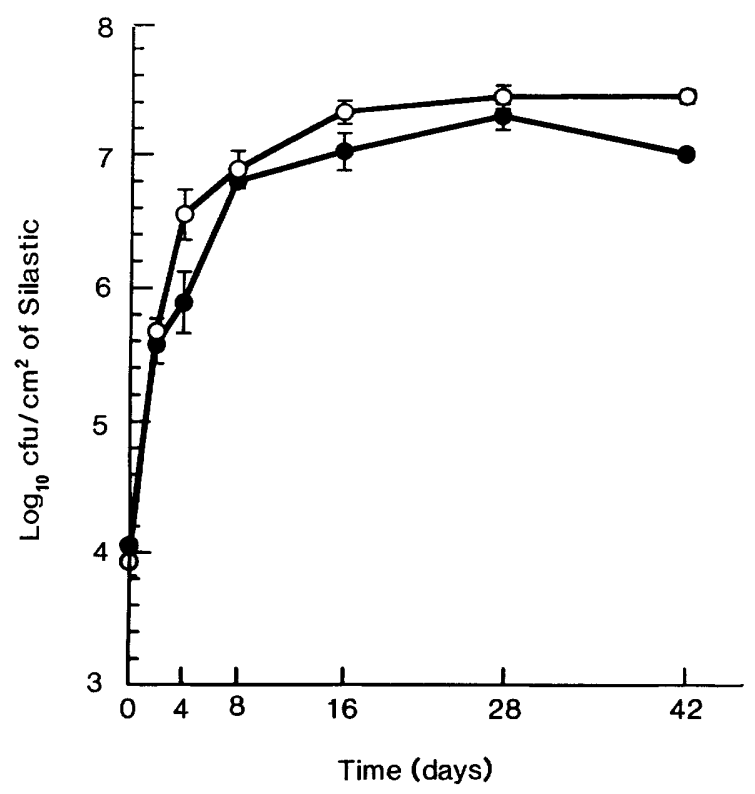

Fig. 5. Growth of $P$. aeruginosa $\left(\log _{10} \mathrm{cfu} / \mathrm{cm}^{2}\right.$ Silastic) on precolonised devices following surgical insertion into the peritoneum. Devices were colonised with $c 1 \times 10^{4} \mathrm{cfu}$ of bacteria $/ \mathrm{cm}^{2}$ and implanted into Group 5, non-immunised (O) and Group 7, immunised $(O)$ rabbits. Each point is a mean value of viable counts on devices from three rabbits. Bars represent SEM.

rabbits at the time of surgery (fig. 4, day 0 ). In immunised rabbits, antibody levels then rose to c. $800 \mathrm{mg} / \mathrm{L}$ by day 4 and fluctuated around this level until day 42 .

A thick biofilm developed on the Silastic surface in both Group 5 and Group 7 rabbits, as judged by TEM and SEM (not shown), and within the biofilm $P$. aeruginosa multiplied rapidly (fig. 5). In both the nonimmunised and immunised groups, viable counts reached $c 10^{7} \mathrm{cfu} / \mathrm{cm}^{2}$ between days 16 and 28 (fig. 5), and remained elevated until the end of the study (day 42). No statistically significant difference in the growth of the bacteria on the device between immunised and non-immunised rabbits was found. All blood and tissues not immediately associated with the devices were sterile on sampling, indicating that the infection remained localised on the device surface.

No bacteria were isolated from the devices that were inserted without pre-colonisation (Group 6), but there was an organised fibrous tissue reaction around the devices when they were removed.

\section{Discussion}

In this study, the ability of the peritoneal cavity of healthy rabbits to deal with a planktonic challenge of $P$. aeruginosa in the presence or absence of an implanted foreign body was investigated. The results confirm that, without an implant, peritoneal defences are well adapted to eliminate a bacterial challenge. This confirms the findings of Skau et al. ${ }^{25}$ who showed rapid peritoneal clearance of an even higher inoculum of Escherichia coli and Bacteroides fragilis. However, if a device is implanted into the peritoneal cavity prior to bacterial challenge, injected bacteria are not destroyed and rapidly colonise the implant creating a chronic device-related infection.

The peritoneal cavity is very well defended against bacterial invasion in the absence of a foreign body. Within minutes of injection, bacteria are rapidly removed from the peritoneum via the lymphatics. ${ }^{25,26}$ They are either filtered out in the retrosternal lymph nodes or passed into the systemic circulation where the reticuloendothelial system clears them from the blood. Blood cultures in this model were negative but were not collected until $24 \mathrm{~h}$ after injection; by which time any bacteria which had passed into the blood would have been destroyed. After lymphatic clearance, peritoneal cellular defences are mobilised. ${ }^{26}$ Analysis of the cellular constituents of lavage fluid from rabbits without implants but inoculated with bacteria demonstrated an increase in the number of phagocytes (PMNs, mesothelial cells and macrophages) with a higher percentage of PMNs $24 \mathrm{~h}$ after injection. These numbers fell to control levels by $96 \mathrm{~h}$. This represents a classic response to a single i.p. injection of bacteria, the influx of bactericidal PMNs occurring within hours of bacterial contamination and reaching a peak within $24 \mathrm{~h}$ if the peritonitis is cleared. ${ }^{26}$ Resident peritoneal macrophages are important phagocytes before the PMN influx and, later, monocyte-derived macrophages infiltrate the cavity to scavenge remaining debris. $^{26}$

Lavage fluid from rabbits that had a peritoneal device and were inoculated with bacteria contained high numbers of phagocytes 24 and $96 \mathrm{~h}$ after challenge. There was also a high percentage of PMNs at these times. It is believed that bacteria not attached to the surface of the device are removed by the active peritoneal phagocytes. However, the latter are clearly unable to destroy the bacteria which colonise the device, resulting in a persistent infection. Therefore, these results are similar to the potentiation of grampositive infection seen with subcutaneous implant materials. ${ }^{20,21}$

The reasons for the detrimental effects of foreign bodies on host defences are not entirely clear although Zimmerli et al. ${ }^{20}$ have defined certain phagocytic defects which occur in the vicinity of subcutaneous tissue cages. In the first few hours local PMN phagocytic and bactericidal activities are reduced, which may be related to decreased superoxide production. ${ }^{27}$ After this time, complement-mediated opsonic activity also decreases. ${ }^{19}$

In addition to phagocytic defects, the device itself provides an inert surface to which bacteria can readily adhere. After initial adherence, bacteria coat themselves with an exopolysaccharide glycocalyx within which they aggregate and multiply, forming microcolonies and eventually extensive biofilms. ${ }^{28}$ Bacterial biofilms were clearly observed on the surface of infected devices in this study and were similar to biofilms found in many clinical prosthetic devicerelated infections. ${ }^{13-16}$ This mode of growth has been 
shown to be a favoured survival strategy of bacteria both in natural aquatic environments and in pathogenic environments in the human body, ${ }^{28}$ and is thought to afford bacteria a degree of protection from adverse conditions and antimicrobial agents.

This study has also demonstrated the failure of host defences to eliminate a challenge of pre-formed bacterial biofilms following insertion of pre-colonised devices. In non-immunised rabbits, the results demonstrated a rapid growth of organisms up to a plateau level about 16 days after insertion of the device. Bacterial counts then fluctuated around this level until the end of the study. In these rabbits, specific antibody levels were very low at the onset of infection and showed only a moderate rise by day 42 . Although immunised rabbits had a 1000-fold higher titre of specific antibody than non-immunised rabbits throughout the 42-day study period, growth of bacteria within the biofilm was not impaired. Specific IgG is considered an important opsonin for phagocytosis, ${ }^{29}$ but its failure, in this model, to enhance phagocytic killing of cells within the biofilm may indicate that antibodies are unable to reach the bacterial cell surface when buried within the biofilm, or that subsequent phagocytosis of the opsonised cells by PMNs and macrophages is impaired. Furthermore, $P$. aeruginosa is known to produce enzymes capable of splitting $\mathrm{IgG}^{30}$ and the biofilm may aid in the concentration of such enzymes.

In conclusion, this investigation has confirmed the increased dangers of infection associated with intraperitoneal implants and has demonstrated that bacteria quickly colonise the device itself, forming biofilms on the implant surface. Once colonised, rapid bacterial multiplication within the more protected environment of the biofilm can occur even if host defences are fully primed by pre-immunisation. Therefore, these results illustrate the enhanced dangers of peritoneal contamination from any source in the presence of a foreign body, and they highlight the special dangers of introducing pre-formed bacterial biofilms on devices that are implanted in the peritoneum.

Finally, the design of the device used in this study allows for easy quantification of surface adherent bacteria and this model is now being used to test other methods of controlling device-related infections within the peritoneum.

We wish to thank Cathy Barlow, Glynnis Broadbent and Ushi Sabharwal for excellent technical assistance. K. H.W. was supported by a grant from the Alberta Heritage Foundation for Medical Research.

\section{References}

1. Dougherty SH. Pathobiology of infection in prosthetic devices Rev Infect Dis $1988 ; 10: 1102-1117$.

2. Sells CJ, Shurtleff DB, Loeser JD. Gram-negative cerebrospinal fluid shunt-associated infections. Pediatrics $1977 ; 59$ : 614618 .

3. Krothapalli R, Duffy WB, Lacke C et al. Pseudomonas peritonitis and continuous ambulatory peritoneal dialysis. Arch Intern Med 1982; 142: 1862-1863.

4. Macbeth GA, Rubin JR, McIntyre KE, Goldstone J, Malone JM. The relevance of arterial wall microbiology to the treatment of prosthetic graft infections: graft infection vs. arterial infection. J Vasc Surg 1984; 1: 750-756.

5. Rosenman JE, Allison DC, Smith DE. Colonic perforation as a complication of peritoneovenous shunt: a case report. Surgery $1984 ; 95$ : 619-621.

6. Abu-Dalu K, Pode D, Hadani M, Sahar A. Colonic complications of ventriculoperitoneal shunts. Neurosurgery 1983 13: $167-169$

7. Snow RB, Lavyne MH, Fraser RAR. Colonic perforation by ventriculoperitoneal shunts. Surg Neurol 1986; 25: 173 177.

8. Krupski WC, Mitchell RA, Gewertz BL, Fry WJ. Appendicitis and aortofemoral graft infection. Arch Surg 1979; 114 969.

9. Hentges DJ. The protective function of the indigenous intestinal flora. Pediatr Infect Dis 1986; 5 Suppl 1: S17-S20.

10. Berg RD. Mechanisms confining indigenous bacteria to the gastrointestinal tract. Am J Clin Nutr $1980 ; 33: 2472-2484$.

11. Gristina AG. Costerton JW. Bacterial adherence to biomaterials and tissue. J Bone Joint Surg 1985; 67A : 264-273.

12. Dougherty SH, Simmons RL. Infections in bionic man: the pathobiology of infections in prosthetic devices, part 1. Curr Probl Surg 1982; 19: 221-264.

13. Marrie TJ, Nelligan J, Costerton JW. A scanning and transmission electron microscopic study of an infected endocardial pacemaker lead. Circulation 1982; 66: 1339-1341.

14. Gristina AG, Costerton JW. Bacteria-laden biofilms: a hazard to orthopedic prostheses. Infections in Surg 1984; 3 $655-662$
15. Marrie TJ, Costerton JW. Scanning and transmission electron microscopy of in situ bacterial colonization of intravenous and intraarterial catheters. J Clin Microbiol 1984; 19: 687-693.

16. Nickel JC, Gristina AG, Costerton JW. Electron microscopic study of an infected Foley catheter. Can J Surg 1985; 28: 50-54.

17. Elek SD, Conen PE. The virulence of Staphylococcus pyogenes for man: a study of the problems of wound infection. $\mathrm{Br} J$ Exp Pathol 1957; 38: 573-586.

18. Noble WC. The production of subcutaneous staphylococcal skin lesions in mice. Br J Exp Pathol 1965; 46: 254-262.

19. Zimmerli W, Waldvogel FA, Vaudaux P, Nydegger UE. Pathogenesis of foreign body infection: description and characteristics of an animal model. J Infect Dis $1982 ; 146$ : 487-497.

20. Christensen GD, Simpson WA, Bisno AL, Beachey EH Experimental foreign body infections in mice challenged with slime-producing Staphylococcus epidermidis. Infect Immun 1983; 40: 407-410.

21. Holloway BW. Genetics of Pseudomonas. Bacteriol Rev 1969 ; 33: $419-443$.

22. Brown MRW, Anwar H, Lambert PA. Evidence that mucoid Pseudomonas aeruginosa in the cystic fibrosis lung grows under iron-restricted conditions. FEMS Microbiol Lett $1984 ; 21$ : 113-117.

23. Costerton JW, Nickel JC, Ladd TI. Suitable methods for the comparative study of free-living and surface-associated bacterial populations. In : Poindexter JS, Leadbetter ER (eds) Bacteria in nature, vol 2. New York, Plenum Press. 1986: 49-84.

24. Ogawa T, Shimauchi H, Hamada S. Mucosal and systemic immune responses in BALB/c mice to Bacteroides gingivalis fimbriae administered orally. Infect Immun 1989; 57 3466-3471.

25. Skau T, Nyström P-O, Öhman L, Stendahl O. The kinetics of peritoneal clearance of Escherichia coli and Bacteroides fragilis and participating defense mechanisms. Arch Surg 1986; 121 : 1033-1039. 
26. Simmons RL, Ahrenholz DH. Pathobiology of peritonitis: a review. J Antimicrob Chemother 1981; 7 Suppl A: S29-S36.

27. Zimmerli W, Lew PD, Waldvogel FA. Pathogenesis of foreign body infection. Evidence for a local granulocyte defect. $J$ Clin Invest 1984; 73: 1191-1200.

28. Costerton JW, Cheng K-J, Geesey GG et al. Bacterial biofilms in nature and disease. Annu Rev Microbiol 1987; 41: 435-464.
29. Spencer RC. Infections in continuous ambulatory peritoneal dialysis. J Med Microbiol 1988; 27: 1-9.

30. Döring G, Obernesser H-J, Botzenhart K. Extracellular toxins of Pseudomonas aeruginosa. II. Effect of two proteases on human immunoglobulins IgG, IgA and secretory IgA. Zentralbl Bakteriol Mikrobiol Hyg I. Abt Orig A $1981 ; 249$ : 89-98. 